\title{
The Question of Anthropological Dualism in the Old Testament and Intertestamental Literature*
}

\section{The Problem of Anthropological Dualism}

Religious dualism, both in history of religion and in theology, can be regarded as one of the most controversial and difficult to explain phenomena. Studies in history of religion are aimed at identifying dualistic traditions in different cultural centers and placing them in the right historical, geographical ${ }^{1}$ and chronological context. The studies on the interdependences of particular traditions and their influence on other, non-dualistic religious movements are particularly challenging because modern researchers still missing certain knowledge or do not have enough data at their disposal. The theological reflection is in a much better position as long as it deals with subsequent phases of development of homogenous religious system.

* STV 7(1969)2.

1 The best publication in the field of ethnology and comparative religions has been presented by U. Bianchi, Il dualism religioso, Roma 1958. In his monographic study he stands that the most important question is: "c'è una connessione obiettiva, fenomenologica e storico-culturale, tra i grandi sistemi dualistici (i dualismi "culti") e i dualismi primitive? (p. 8). For this paper, of certain importance are some author's remarks regarding the Iranian and gnostic dualism, together with his discussion about dualism as a worldwide religion within the Gnosticism (Gnosis als Weltreligion, p. 13 and following). See also a series of papers discussing the same topic published by U. Bianchi in a collective cahier of a meeting in Messina dedicated to the question of Gnosticism: Le origini dello gnosticismo - The origins of Gnosticism, Leiden 1967. Also W. Eltester, in his book Christentum und Gnosis, Berlin 1969, pp. 129-132 mentions the interesting theses of the Messina meeting regarding the relation between the Gnosticism and dualism, and a correct use of both terms. 
Much more difficult to capture are, however, secondary foreign dualistic influences, which hardly ever could be distinguished from the development of indigenous, original religious thought in its radical form. The difference between an externally adopted dualistic idea, adapted and then incorporated into a theological system and between its influence, intensely stimulating an indigenous, original reflection in a certain direction does not seem to be significant.

There is a common tendency to subsume not only the notion of the real bifurcation of reality into two poles, which are irreducible to each other (proper dualism) or into two opposite elements, but also all tendencies to create oppositions, contrasts or antitheses (relative dualism) into the overall notion of dualism. The anthropological dualism, which is the subject of the present paper, is not limited, however, to a Platonic-Orphic concept of the body, considered as a prison of the soul ${ }^{2}$, even though this opposition is going to play a rather fundamental role here.

Significant part of our considerations will be focused on the disparity between the two major constitutive elements of a human being, the inferior of which (usually referred to as body) becomes subject to a negative judgment or even disgust ${ }^{3}$.

Certainly, we should not expect to find in the Old Testament or in the Qumran documents a consistent lecture on the anthropological dualism. Considering the monistic presuppositions of the books of the Old Covenant in terms of human science (discussed later in this paper) and taking into account the attitude of careful distance - with regard to any form of dualism - kept by biblical traditions, only a practical approach, which simply opposes some non-dualistic anthropological concepts, is possible.

A similar situation can be found in non-biblical intertestamental literature, in particular in the Qumran documents. In this category, different literary genres can be distinguished. If, for instance, in parenetic (Test. XII Patr.) or didactic-legal treatises (The Qumran Community Rule), the anthropological dualism is a way of expressing a dissonance concerning ethics and respecting the Law, then in Apocalyptic writings or hymns this kind of dualism will justify spiritual struggles and dilemmas present in religious life. In both cases the anthropological assumptions is of secondary importance.

There are, however, certain fragments, in the Qumran literature, in which the didactical tendency gives way to theological exposition. But even there, the

2 See G. Mensching, Dualismis I, 4. In: Die Religion in Geschichte und Gegenwart ${ }^{3}$ vol. III, 273.

See G. Van der Leeuw, Phänomenologie der Religion², Tübingen 1956, 342. 
anthropological dualism is not considered an independent issue, but is always examined together with an ethical dilemma or even with cosmological bifurcation.

Both elements fighting each other inside a human heart represent two very different ethical values: the good and the bad. The fight between them is not only typically human; similar rivalry can be found on the cosmic level and its forces can influence a human life in a positive or negative way.

Both in the Old Testament environment and in circles where intertestamental literature was created, there is no point in distinguishing classical types of dualism, also it creates a risk of learning about its specific characteristics. What is important is that the main theater of this rivalry is the human, whose all powers participate in it. This is why, when examinig issues constituting anthropological dualism, we actually deal with a whole spectrum of antithetic theses that come together with it.

The issue of anthropological duality and its origins was taken up with the finding and publication of, today widely known, Qumran texts. In these texts, not only antitheses and practical dualistic concepts, well-known from the Old Testament, have been found for the first time, but also a compact lecture on the dualistic view of human life.

It is not surprising then that from the very beginning of this research, the question of origins and foreign influences of the dualistic doctrine has been imposed ${ }^{4}$.

Although the issue of the genesis of Qumran human studies has been initially examined only occasionally, two tendencies have emerged in its course: one regarded anthropology of the Qumran Community only as a specific interpretation of the Old Testament teaching, enriched with some sharp contrapositions, to be found also in other intertestamental texts ${ }^{5}$, the other argued in favour of maintaining a fundamental distinction between the biblical tradition and the Qumran dualism, difficult to be derived from the influence of a late-Jewish Apocalyptic ${ }^{6}$.

$4 \quad$ K. G. Kuhn, Die Sektenschrift und die iranische Religion, Zeitschrift für Theologie und Kirche, 49 (1952) 296-316; A. Dupont-Sommer, L'instruction sur les deux Esprits dans le „Manuel de Discipline", Revue de l'Histoire des Religions 142 (1952) 5-35; ibidem, Le problème des influences étrangères sur la secte juive de Qoumran, Revue de l'Histoire et de Philosophie religieuses 35 (1955) 75-92; H. Wildberger, Der Dualismus in den Qumranschriften, Asiatische Studien 1 (1954) 163-177.

5 See E. Schweizer, sarx. In: Theologisches Wörterbuch zum Neuen Testament VII, 118-121.

6 Cfr in particular a paper by H. H. Rowley, Jewish Apocalyptic and the Dead Sea Scrolls, London 1957 
The radicalism of this approach would indicate - as claimed by the followers of the second tendency - not only the existence of non-biblical influences, but also of a completely foreign influences, such as Iranian ${ }^{7}$, early Gnostic ${ }^{8}$ or even proto-Mandaeic'. Both extreme positions have been later criticized, which however has not contributed to achieve definite solution of the anthropological problem in terms of dualistic perspective of Qumran.

After the publication of most of the texts ${ }^{10}$, further fragments of wellknown inter-testamental Apocryphs representing a similar dualistic anthropology were found there. This gave rise to the assumption that they might be of the same origins as the Qumran manuscripts. This particularly refers to the Testaments of the Twelve Patriarchs, a writings that was characterized by dualistic assumptions most closely related to the Community Rule or Qumran Hymns.

Today it commonly stated that this apocryphal writing has its origins in an environment that had some contacts with Qumran ${ }^{11}$, while the current views indicate significant influence of Christianity, regarding it even as a Christian writing ${ }^{12}$.

7 Apart from works cited in comment no. 4, see also H.Michaud, Un mythe zervanite dans un des manuscrits de Qumran, Vetus Testamentum 5 (1955) 137-147; A. Vööbbus, History of Ascetism in the Syrian Orient, Louvain 1958, 20-22; J. Danielou, Demon II, 2 in: Dictionnaire de Spiritualité III, 162.

8 Some commentators did not hesitate to consider the Qumran manuscripts the oldest Gnostic document: K. Schubert, Der Sektenkanon von En Feschha un di Anfänge der jüdischen Gnosis, Theologische Literaturzeitung 78 (1953), 495-506; H. J. Schoeps, Das Gnostische Judentum in den Dead Sea Scrolls, Zeitschrift für Religions-und Geistesgeschichte 4 (1954) 276-279; R. Marcus, Judaism and Gnosticism, Judaism 4 (1955) 360-364; Bo Reicke, Traces of Gnosticism in the Dead Sea Scrolls?' New Testament Studies 1 (1954/1955) 137-141 (a moderate position; mentions only pre-gnosis seen as stage of the development of the doctrine of Judaism). The broadest justification of gnostic elements found in the manuscripts can be found in I. H. Braun, Spätjüdisch-häretischer und frühchristlicher Radikalismus I-II, Tübingen 1957.

$9 \quad$ F. M. Barun, Le Mandeisme et la secte essenien de Qumrân, in: L'Ancien Testamen et L'Orient (Louvain 1957), 193-230. To be noted also an older paper by K. Stawarczyk, Protomandaizm a powstanie gnozy (Proto-Mandaeism and the origins of Gnosis), Collectanea Theologica 16 (1935) 519-530 (partly outdated).

10 Until now, entire manuscripts and fragments from caves 1-3 and 5-10 have been published, from caves 4 and 11 only the most important documents have been published and a critical edition shall be published soon.

${ }^{11}$ In Caves I (1Q 21) and IV (4Q TLevi ara ${ }^{\mathrm{a}^{-}} \mathrm{c}$; 4Q TNapht hebr.) some prototypes of fragments of the Testaments of the Twelve Patriarchs written in Aramaic and Hebrew have been found. Further information provided in: J.T. Milik, Le Testament de Lévi en araméen. Fragment de la Grotte 4 de Qumrân, Revue Biblique 62 (1955) 398-406.

12 This has been suggested, independently from the Qumran writings, by M. De Jonge, The Testament of the Twelve Patriarchs, Assen 1953. 
This - indeed problematic - explanation is not satisfactory, because it does not explain the origins of dualistic anthropology, it only brings it down to one source, not considering other constitutive elements of development of biblical anthropological concepts.

Neither the late-Jewish teching on the two tendencies (jesarim) of human being ${ }^{13}$, nor the late-Hellenic ${ }^{14}$ Judaism explains sufficiently the dualistic orientation of anthropology in the intertestamental literature. Therefore, a retrospective review of this antropology, both in terms of its assumptions and its numerous implications, seems indispensable. The basis of this research will be, of course, the Old Testament, to which the intertestamental literature constantly refers.

Because the thematic scope of this article does not allow to discuss exhaustively all aspects of dualistic anthropology, we should limit ourselves to one - the most characteristic antithesis: body-spirit. It will allow us to capture the fundamental difference between the dualistic biblical and Hellenistic concepts, on the other hand, it is of considerable importance in the view of further development of biblical anthropology in the New Testament.

\section{Body and Spirit in the Old Testament}

The Hebrew Bible considers the human being an organic entirety, not affected by a distinction between individual functional organs like the heart (lēb), the life-giving element (nefeš) etc. ${ }^{15}$ Older biblical theologies of the Old Testament, persistently aiming at adapting the biblical data to Greek-Latin schemes ${ }^{16}$ were trying to distinguish two (nefeš - the vegetative soul and rûah - the "spiritual"

13 For the „two tendencies” see excursus: The heart's vicious intentions in L. Stachowiak, Lamentacje - Księga Barucha (Lamentations - the Book of Baruch), Poznań 1968 147-157.

14 See i.e. B. Otzen, Die neugefundenden hebräischen Sektenschriften und die Testamente die Zwölf Patriarchen, Studia Theologica 7 (1953) 125-157.

15 Widely described in papers researching more general anthropological principles of the Old Testament. See in particular: K. Galling, Das Bild vom Menschen in biblischer Sicht, Mainz 1947; G. Fohrer, Theologische Züge des Menschenbildes in Alten Testament. In: Das Wort im evangelischen Religionsunterricht 1959/60, nr 1, 9-21; W. Zimmerli, Was ist der Mensch, Göttingen 1964; V. Warnach, Mensch., in: Handbuch Theologischer Grundbegriffe (Münschen, 1963), vol. II 145-160; L. Köhler, Theologie des Alten Testaments ${ }^{4}$, Tübingen 1966.

16 I.e. J. Schwab, Der Begriff der Nephesch in den Religen Schriften des Alten Testaments, München 1913; R. Dussaud, La notion d'âme chez les Israelites et les Phéniciens, Syria 16 (1935) 267-277. 
soul) or even more (nefeš, rûah and baśar, the body) constitutive elements in anthropological disputes. ${ }^{17}$

These, however, include neither rûah nor baśar, which can be defined as different aspects of one, given psycho-physical subject. It is difficult to consider the divine origin of the spirit ${ }^{18}$ as the basis for a more accurate distinction, because according to the testimony of the Bible, every element of a human has ultimately divine origins. The Old Testament considers a living body and all of its parts as one entity constituting each person's individual life; in the individual "parts" of an animated body, all of his personality may manifest. Undoubtedly, the ability to provide comprehensive representation of the manifestations of life of an individual in its seemingly separate aspects, is an original characteristic of the Hebrew way of thinking. ${ }^{19}$

The Hellenistic culture has brought a completely different point of view of an individual to the East. In his structure, two completely different elements can be distinguished: body (rather soma than sarx - see below), exponent of the material side, the inferior aspect of man's existence, and soul (psyche), of divine origin, which is striving to free itself from the bonds of the body.

Admittedly, it is not the aim of this paper to present the genesis and development of these views.

It is enough to quote the classic formulation of the most outstanding representative and theoretician of these views, Plato, who in his "Phaedo”, XI (66b- 67b) states as follows: “....as long as we do have a body (to soma), and our soul will be linked to such a great evil, never in the world are we able to achieve and own what we desire. And we say that this is the truth. Because the body, which requires nutrition, is the cause of problems... ... It fills us with desire, lust and fears and illusions of all kinds, and lots of nonsense, so that as they say we cannot ever take something in only by brain. Because all wars and riots and battles, they come from the body and its desires. Because all our wars are about getting the money, and the money is acquired for the body; like slaves we are obliged to accommodate it. And this is why we have no time to dedicate

17 Widely described by: A.I. Festugière, L'idéal religieux des Grecs et l'Evangile, Paris 1932, 196-222; P. van Imschoot Theologie de l'Ancien Testament, Paris 1956, vol. II, 35; W. Eichrodt, Theologie des Alten Testaments ${ }^{4}$, Göttingen 1961, vol. II/III, 75-99.

18 See L. Stachowiak Teologiczny temat duchów w pismach qumrańskich (The theological topic of the Spirits in the Qumran writings), Zeszyty Naukowe KUL-u 10 (1967) 37-52, particularly p. 38 .

19 See also A.R. Johnson, The Vitality of the Individual in the Thought of Ancient Israel ${ }^{2}$, Cardiff 1964; A.S. Kapelrud, Mensch, In: Die Religion in Geschichte und Gegenwart ${ }^{3}$, vol. IV, 863. 
to philosophy... We actually have just this one indication, that if one of us wants to learn something in a pure way, they have to set free from the body and look at the soul alone, at the reality... Because if it is impossible, being inside a body, to see anything purely, there are only two choices: either we cannot acquire the knowledge ever, or only after we die. Then the soul will be separated from the body, which it was not before. And as long as we live, the closest we can get to cognition is if we do not consort with the body, if we do not have in common with it anything more than ultimate necessity, if we are not full of its nature but are free of its stigma, before god sets us free. Then, pure and liberated from the body's mindlessness, undoubtedly we will be surrounded by others like us and will by ourselves discover and learn all that is immaculate. And this is probably the truth" ${ }^{20}$

In the anthropological investigations, philosophical terminology has been adopted, which allowed to define both views of man as "monism" and "dichotomy" (or even "trichotomy"), or more generally as dualism or pluralism. ${ }^{21}$ These terms however, can be slightly misleading if they are applied to the Bible, including even the New Testament.

They place the problem of biblical antitheses in a context that is rather alien to them. Since while the ancient Greek used to shape his image of man based on a philosophical reflection, the biblical approach is mainly the result of religious experience, and only to a small degree, of theological thought. The Bible thoroughly discusses the relation between man and God in all its aspects, while saying not much about the anthropological and psychological structure of man.

Therefore, before attempting to analyze the "body" and "spirit" in their authentic relationships, it should be stated that it will be rather a series of miscellaneous assumptions and reflections upon the essence of man, than a systematic anthropology.

The first lexicographical encounter with the Hebrew notion of bāsa $\bar{a} r$ in the Old Testament gives the impression of a complete differentiation of meanings. ${ }^{22}$

20 Translation by Marta Kostyk-Konik.

21 See i.e. S. Laeuchli, Monism and Dualism in the Pauline Anthropology (Biblical Research III 1958), 15-27 and P. van Imschoot, op. cit. II, 35.

22 Among the newer synthetic reviews, we shall mention: J. A. T. Robinson, The Body, London 1957, 11-16; O. Kuss, Der Römerbrief. Excursus: Fleisch II (Regensburg 1959) 529-530; A. Stöger, Fleisch, in: Bibeltheologisches Wörterbuch ${ }^{3}$ vol. I, 390-397; X. Léon-Dufour, Chair, in: Vocabulaire de Théologie Biblique (Paris 1962), 112-117; E. Schweizer, op. cit., 105-109; J. Fichtner, Fleisch und Geist., in: Die Religion in Geschichte und Gegenwart³, vol. II 974-976; J.Scharbert, 
For the present paper, of no importance will be the bśr meant as part of the human body, one covering the skeleton ${ }^{23}$, of a man or animal (Gen. 41, $2,19)$ or parts that are under the skin (i.e. Psalm 102, 6), even though this last meaning is probably the original one. ${ }^{24}$ Not too much can be deduced from the collective term of kol basśár, which designates all living creature, both animals and people (i.e. Gen. 6, 17. 19; Psalm 136, 25).

The Hebrew term sometimes also refers to the body of non-living beings, as is indicated eg in 1 Sam 17, 44; 4 Kings 9.36. The term bśr - which appears in these and similar texts - refers not only to the community of physical life, but also to the created and transient condition of corporeal creatures. Thus, it designates "each and every body", a sort of transition to a metaphorical, or rather theological sense of the term which is of utmost importance for the explanation of this antithesis.

The key to understanding the concept of the "body" in the oldest writings of biblical tradition is the verse (Genesis 6, 3): "My spirit shall not always strive with man, for that he also is flesh (hû' bāśär): yet his days shall be an hundred and twenty years." he will live one hundred and twenty years. "Not without significance for the proper understanding of bśr in the text quoted above is the verb jādôn, which is usually explained in various ways.

According to the established norms of the Masoretic spelling should be combined with the core dîn (to judge), which, however, would be unacceptable in this context. It is not known what prompted LXX to translate this phrase ou me katameine as "shall not abide with" or "can not abide with". Contemporary commentaries suggest a variety the meaning of the word: beginning from the Akkadian danau (to be strong, powerful) to the Arabic dâna (to be humiliated $)^{25}$.

This last explanation was recently taken up and justified by J. Scharbert ${ }^{26}$ In his opinion, the basic meaning of the word is "of low value, bad" (like Accadic dunnati, an inferior thing), which would provide Genesis 6.3: "My spirit shall not

Fleisch, Geist und Seele im Pentateuch (Stuttgarter Bibelstudien 19), Stuttgart 1966; A. Sand, Der Begriff „Fleisch” in den paulinischen Hauptbriefen, Regensburg 1967; P. van Imschoot, Fleisch., in: Bibel-Lexikon² (Einsielden 1968), 482-486.

${ }^{23}$ See i.e. Gen 2, 21 where God, after having cut off Adam's rib, fills the remaining space

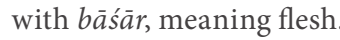

24 E. Schweizer, op. cit., 105, 15.

25 A. Clamer, La Genèse, Paris 1953, 177.

26 Traditions- und Redaktionsgeschichte von Gen 6, 1-4, Biblische Zeitschrift NF 11 (1967) 66-78, in particular 67. 
always lose value in man, for that he also is flesh"' ${ }^{27}$.with the following meaning. The suggestion of $\mathrm{Cz}$. Jakubiec ${ }^{28}$, who argues for maintaining the din core, by referring to its another meaning - which is "to fight", known from Koh 6, 10.

Apparently, dîn is not just a technical judicial term, but it can mean any discussion or even a fight (which results among others from Sam 19, 10). It would be, then, the oldest example of statement about the contradiction between the "spirit" and the "body" and maybe even a struggle between the two. Bāśăr, the body, would correspond here to the symptom of weakness and imperfection of the human nature together with all their consequences, such as sensuality and excitability. ${ }^{29}$ Such a condition of the human body does not allow for the unlimited presence of God's element in it, which is the spirit.

An analysis of the literary tradition of this interesting statement goes even further. It is commonly attributed to the Yahvist tradition, following the famous commentator H. Gunkel, even though such a prominent expert on source analysis of the Pentateuch as M. Noth ${ }^{30}$ speaks about the origin of this passage in a very restrained manner. Closer analysis of Yahvist anthropology questions the validity of attributing Gen 6, 1-4 to J. This tradition avoids using the term "spirit" in the anthropological sense, i.e. as a natural equipment of an individual. ${ }^{31}$

According to Gen. 6: 1-4, it will be naturally regarded as crucial to undertake the attempt of original elaboration of the text, instead of subsequent supplement elaborations, whose anthropological assumptions are completely unknown today. The Yahvist has already indicated the causes of the flood in 4, 1- 24 and continues in Gen. 6, 5 in a completely natural way. ${ }^{32}$ More interesting, however, is that in the J source, the "spirit of Yahve" means rather the charism of God than the universal attribute of man, and the concept of body is never assessed as it is in 6,3 . The $\mathrm{P}$ source provides us, however, with much more data about this concept, by attributing to man the "spirit of life" (not the "breath of life," as the Yahvist does, beginning with Genesis 2: 7) in 6, 17 and 7, 15.

27 Other solutions suggested by: E. G. Kraeling, The significance and Origin of Gen 6, 1-4, Journal of Near Eastern Studies 6 (1947) 193-2-8 and J. Fischer, Deutung und literarischer Art. Von Gen 6, 1-4. In: Festschrift F. Nötscher (Bonn 1950) 74-85; J. B. Bauer, Die biblische Urgeschichte2, Paderborn 1964, 57-69.

${ }_{28}$ Genesis - Księga Rodzaju (Genesis - The Book of Genesis), Warszawa 1957, 110.

29 Ibidem, 110.

30 Ueberlieferungsgeschichte des Pentateuchs, Stuttgart 1948, 29, 83.

31 J. Scharbert, Fleisch, Geist..., 18-22 and 35-36; J. Scharbert, Traditions- und Redaktionsgeschichte von Gen 6, 1-4, 70.

32 J. Scharbert, Traditions- und Redaktionsgeschichte von Gen 6, 1-4, 69. 
Admittedly, the fact that, after determining the age limit of 120 years, the editor included in this group the Patriarchs, who lived much longer, cannot be regarded as decisive argument. ${ }^{33}$ It merely proves that this fragment is not part of the main editing body of source P. In this case, however, the origins of the tradition should be considered a decisive factor, and not the time when it was elaborated.

J. Scharbert legitimately indicates analogies with the $\mathrm{P}$ source which is supposed to confirm his supposition ${ }^{34}$, less clear is the juxtaposition of the text with Ez 37 and re-timing of the edition of this fragment to the times of Ezra and Nehemiah or even early Apocalyptic. The last statement would be interesting insofar as it would allow us to refer anthropological speculations to the emerging view on "spirits" considered as angels (see context of Gn. 6, 3!). Whether Persian influences should also be assumed - in the discussed period - it is impossible to settle by now.

Rather, the antithetic tendencies of the sacerdotal tradition should be considered - which will be discussed below.

Even though bśr can be derived, as the whole human being, from the act of creation by God, since quite early times it has been represented as the element least susceptible to the actions of the spirit.

This is why it occupies sometimes opposite positions in the very clear contrasts of the prophetic speeches: "But the Egyptians are mere mortals, and not God; their horses are flesh and not spirit" (Is 31, 3). This interesting sentence comes from a speech condemning the irresponsible policy of alliances of the nation of Judah. Other contrapositions of this kind are contained in Ps 56, 5, and, in particular, in Is 40, 6-7: "All people are like grass, and all their faithfulness is like the flowers of the field. The grass withers and the flowers fall, because the breath of the LORD (Yahve, rûah jahweh - a word play?) blows on them. Surely the people are grass."

Thus, the concept of the human body includes everything that is transient, mortal, weak and limited, as opposed to the power, infinity and infinitude of God, represented by the "spirit" in a human being, regardless of whether it is the spirit of God or the spirit considered as a natural human's feature. ${ }^{35}$

33 J. Scharbert, Traditions- und Redaktionsgeschichte von Gen 6, 1-4, 70-71.

34 See texts cited above, Gen. 6, 17 and 7,15.

35 J. Fichtner (Fleisch und Geist I. In: Die Religion in Gescichte und Gegenwart ${ }^{3}$, II, 975) describes it accurately: Der Gegesatz von Fleisch und Geist ist weder substantiell noch ethisch bestimmt, sondern eher dynamisch-funktional; hinter dem Gegenüber von Macht und Ohnmacht erscheint der Gegensatz ewig-vergänglich, dh aber Schöpfer-Geschöpf. 
Nevertheless, the Hebrew Bible has not elaborated this difference to the dimension of the opposition between the spirit and the body, even less so to the difference between the body and God. On the ethical level it has not clearly relate the body with the sin or the propensity to it. Nevertheless, it has made way, for further considerations, influenced by different factors.

\section{Body and Spirit in the Hellenic - Jewish Tradition}

The first contact between the original Hebrew thought and the elements of a radically different greek-hellenistic views ${ }^{36}$ have not from the very beginning introduced fundamental changes in the concept of the body. The books of the Old Testament, written under the influence of the Greek culture (or even written in Greek) make clear reference to the well known Old Testament meanings, among which of a significant importance is the Hebrew notion $b \bar{a} s \bar{a} a$, meaning the external, mundane existence of an individual (i. e . Sir 31, 1).

Undoubtedly, a great role has been played here by the double concept of body in the Greek culture. Apart from a simple equivalent of the Hebrew bśr, the Greek sarx, there is another one, aforementioned in the Phaedon of Plato, the soma. ${ }^{37}$ Actually, in Hebrew, there is no direct equivalent of soma; therefore whenever LXX used it, there are eight different Hebrew words corresponding to it.

A more detailed differentiation between sarx and soma would be almost tantamount to presenting a specification of differences between the Greek and the Biblical anthropology. To put it synthetically ${ }^{38}$, it should be stated that soma always refers to a basic distinction between the matter and the form, describing the result of shaping the corporeal substance into a particular form. ${ }^{39}$

In this way, the Hellenism can create a contraposition of soma and sarx, but it can speak also of soma (tes) sarkos (Sir 23, 17 - see Col 1, 22; 2, 11 and

\footnotetext{
36 Probably these contacts took place before Alexander the Great's expedition - see D. Auscher, Les relations entre la Grèce et la Palestine avant la conquête d'Alexandre, Vetus Testamentum 17 (1967), 8-30.

37 The Hebrew baśar has been translated in LXX quantitatively respectively as (together with the Hebrew text of Sirach): 145 times as sarx, only 23 times as soma.

38 More about it in a paper by J. A. T. Robinson, The Body, 13-15. Special attention should be paid to a historical perspective of the development of the Greek concept of soma in E. Schweizer, soma., in: Theologisches Wörterbuch zum Neuen Testament, vol. VII, 1025-1042.

39 As J. A. T. Robinson (op. cit. 13) notices, the Hebrew anthropology does not need to reach for this differentiation, considering a human bein a one, living, psycho-physical substance.
} 
further). Soma, unlike sarx, always designates a human being as a whole, only intended as an individual, and never, unlike sarx, does it designate all people or all corporeal beings in general.

The real contraposition of the Greek anthropology, body-soul, consists in the distinction between soma and psyche. ${ }^{40}$ Although man has a sarx, but his being is a soma, a piece of matter shaped into an individual, with a soul incorporated in it, striving to be released from it. In a comprehensive Hebrew approach, this kind of distinction is simply redundant.

The most important difference, for the antithesis between body and spirit, between the two concepts is the lack of any symptom of weakness and transience in soma. In order to express such a concept, an exponent of this weakness, sarx, needs to be added (soma tes sarkos, as mentioned above).

In the case of the biblical antithesis discussed (soma will also play almost marginal role); the contraposition can only exist between the spirit and the body understood in the sense of sarx.

The dualistic approach to the problem of the body in Hellenistic anthropology could not have been without effect on the formulation of Greek-Judaic literature, despite attempts to translate the revealed concepts into the language associated with pagan concepts as accurately as possible. Hence, Hellenic-Jewish translators tend to strictly follow the distinction between soma and sarx, explaining, for example, Pr 5, 11 (see Job 41, 15) baśar ûse'er as sarkes tou somatos.

More important, however, is the fact that the essential Biblical distinction between the Creator and creation, in the anthropological perspective, which is expressed through the opposition between the spirit and the body, begins to acquire cosmic qualities. For example, the Hebrew phrase (Lb 16, 22 - compare 27,16 ' 'e lohê hârûhôt lek'l baśar is translated by LXX in the following way: theos ton pneumaton kai pases sarkos, thus distinguishing between the sphere of the 'soul'and the sphere 'body'. Of course, we are far here from achieving the appropriate dualism between the body and the spirit as two spheres present in man, nevertheless the oldest Greek translation of the Bible indicates the further possibilities of the development in this very direction. ${ }^{41}$

40 See the abovementioned text of Plato, Phaedon 66b - 67a. It is doubtful if the great philosopher made a difference between sarx and soma - see also W. Stacey, The Pauline View of Man, London 1956, 74: Sarx in Plato did not differ essentially from soma.

${ }^{41}$ See E. Schweizer, sarx. In: Theologisches Wörterbuch zum N. T., vol. VII, 108, 14-26.The author's assertion, however, that the most influential factor here was die persische Konzeption einer geistigen Welt, die sich über der irdischen erhebt seems to be quite groundless. Certain relations of the Iranian worldview (probably also dualism) with the younger canon books of the Old 
Other Hellenistic-Jewish texts either continue the same cosmic-dualistic developmental line $e^{42}$, or grant it a more anthropological sense. There are also more distinct attempts to transfer the original Greek dualism to the sphere of the revealed word of God, especially in Wisdom 7, 1- 2. 7, in the apocryphal writings 4 Mch 7, 13, in $\mathrm{Henoch}^{43}$ and in the book of Jubilees. ${ }^{44}$ The authors of these books not only clearly refer to the two spheres, but also highlight the distance and dissonance between the body, the source of lust and the spirit, pneuma.

A similar position is generally held by Filon of Alexandria. According to him, man consists of the sphere of the body (sarx) and the sphere of the spirit (pneuma), with the body being - according to the Greeks - regarded as the inferior, sinful part of man.

The statement by Józef Fawiusz about the anthropology of the Essenes, to which Qumran people belonged, also has a more problematic character; it would be a concept very similar to the Greek dualism of body and soul. "The body is fragile in its nature and the matter it consists of is transient, every soul is in turn eternally immortal, and consists of an elusive ether and is supposedly imprisoned by nature into body, but then freed from bodily slavery, as if after a long suffering, it is blissfully flying to the heights. ${ }^{45}$ Leaving aside the statement of Józef Fawiusz, which can be regarded as an obvious compromise in favour

Testament are hard to question if one considers the long period of Persian hegemony in Palestine, and more so the relations with the diaspora. The borrowings, however, seem to be of secondary importance and do not interfere with the essential doctrinal premises of St. Testament; nor can there be confirmed any visible Iranian influence on biblical anthropology. In Judaism, such influence may be taken into account, especially when considering the characteristic theory of the "two spirits" in Qumran (1QS 3, 13nn) and in the Testaments of the Twelfth Patriarchs (see more on this subject in: L. Stachowiak, Temat dwóch duchów (The Problem of two spirits)..., 42-43); however, here too, the interdependence - with regard to tradition - between Judaism and Gathami (especially Yasna 30,3n) is not simple or direct. If intertestamental Judaism succumbed to Iranian influences, it was certainly not the classical doctrine of Zarathustra, but rather the Chaldean-Iranian syncretism, consisting especially in the elements of Zerwanism. See also R. Meyer, Monotheismus in Israel and in Religion Zarathustras, Biblische Zeitschrift NF 1 (1957) $48 \mathrm{ff}$

42 For example, Jub 2, 2.11 and 10, 3: "God of spirits who are in all bodies"; I Hen 15, 4, 8; Philon of Alexandria, De virtut. 58 and part.

43 The exact list of texts is provided by E. Schweizer, art. cit., 119n.

44 This is discussed in more detail in M. Testuz, Les idées religieuses du Livre du Jubilés, Genève-Paris 1960.

45 Bell. Jud. II, 154- 155 (ed. by B. Niese, Flavii Josephi Opera -, Berlin 1955, vol. VI, 183n); translated by E. Dąbrowski, Nowy Testament na tle epoki II (The New Testament in the context of the period), Poznań 1958, 212. 
of the Hellenic approach, it is certain that the Greek-Jewish writings are only a step away from presenting the body as the source of sin; however, neither the Old Testament nor the apocryphal literature has made this crucial step.

Under the influence of a new, revelatory view of man, this step will be made by the New Testament, especially by St. Paul. Some utterances of the Testaments of the Twelfth Patriarchs, which explain the deceptive activities of the spirits of iniquity by referring to the bodily nature of man (sarx - Test. Acts 9,7), or present the body as contaminated with sin (Test. Jude 19, 4) can not be decisive in this matter. ${ }^{46}$ Nevertheless, these oppositions gain ${ }^{47}$ a peculiar meaning when compared with other dualistic statements in the Test. XII Patr. - naturally as long as they do not have the character of interpolation or are not elements introduced by a later Christian editor. ${ }^{48}$

Antithetic formulations of Saint Paul and the captivating description of the internal struggle presented in Gal 5 and Rome $7-81^{49}$ on the one hand, continue the Old Testament line, and on the other, open up completely new, as it seems, original perspectives. As for the contraposition of the body-spirit, in the letters of St. Paul, discussion has been going on for years, not yet settled or completed. Admittedly, all possible sources were proposed: the Old Testament, Greek dualism, rabbinicism, gnosis, Hellenic Judaism, Qumran. Some of these attempts tend to find a source equivalent to each of the anthropological

46 "I was blinded by the master of error (archon tes planes), I was unconscious like a man, like a body tainted with sin."

47 Cf. L. Stachowiak, Temat dwóch duchów..., 40.

48 Cf. L. Rost, Testamente der XII Patriarchen. in: Die Religion in Geschichte und Gegenwart3, vol. VI, 701-702 and J. Murphy- O. Connor, Testamente der zwölf Pariarchen. in: Bibel-Lexikon 2 (Einsiedeln 1968), 1733 - 1735, who strongly reject the hypothesis of the Christian origin of the Testaments, assuming the existence of its three successive aspects: the first of the Syrach period (Qumran influences?), the second of a strongly-emphasized Messianic character dated the first century BC and the third Christian from the first or second century after Chr. The dependence between the individual aspects and influences that contributed to their formation should be subject to a more thorough explanation.

49 Cf. E. Ellwein, Das Rätsel von Römer VII; Kerygma und Dogmal (1955) 247-268; W. Matthias, Der alte und der neue Mensch in der Antropologie des Paulus, Evangelische Theologie 17 (1957) 385- 397; W. H. Taylor, The antithetic Method in Pauline Theology, doctoral dissertation. Northwestern Univers. 1958 (microfilm); H. Braun, Röm. 7, 7-25 und das Selbstverständnis des Qumran-Frommen, Zeitschrift für Theologie und Kirche 56 (1959) 1- 18; W. Keuck, Dienst des Geistes und des Fleisches. Zur Auslegungsgeschichte und Auslegung von Röm 7,25b, Tübinger Theologische Quartalschrift 141 (1961) 257-280; O. Kuss Römerbrief II, Regensburg 1960, 506-595; A. Sand, Der Begriff „Fleisch” in den paulinischen Hauptbriefen, Regensburg 1967. 
elements. ${ }^{50}$ Undoubtedly, the Judaic dogma of two eons, typical of the intertestamental Apocalyptic, has had a significant influence in this matter ${ }^{51}$ : "old eon" represents the inner struggles and tearing of a man, and spirit and body are their exponents and extremes; "eon new" or "future eon" will be characterized by the indivisible rule of the spirit. ${ }^{52}$ Certainly, however, the conviction of the body as subjected to weakness or even to contamination had a constructive implications with regard to the theological reflection of the apostle from Tarsus. The very transition, however, from the concept of the body as an earthly and temporal sphere, which is contrasted with the sphere of God (spirit sphere), moreover, the transition from the body, the exponent of the natural physical and moral weakness to the body regarded as the subject of sin, fallen under the dominion of the power of darkness ${ }^{53}$, finds no justification in the sources discussed so far.

J. Nélis ${ }^{54}$ rightly points out that the contribution of St. Paul to a new, deepened understanding of the antithesis of the body-spirit is more significant than assumed by the biblical criticism. In view of the described state of affairs, the retrospective derivation of the more precise content of this antithesis in the Old Testament's and Intertestamental sources from these statements would be risky, although the general direction of development - radicalization of views on the role of the body in man - would correspond to Judaic tendencies.

50 Cf. for example D. Flusser, The Dead Sea Scrolls and Pre-Pauline Christianity, Studia Hierosolymitana IV (1958) 215-266, especially 252-263; K. G. Kuhn, New Light on Temptation, Sin and Flesh in the Scrolls and in the New Testament. in: The Scrolls and the New Testament (New York 1957), 94-113; J. Pryke, „Spirit” and „Flesh” in the Qumran Documents and some New Testament Texts, Revue de Qumran 5 (1965) 345-360; R. Scroggs, The last Adam, Oxford 1966; O. Sander, Leib-Seele Dualismus im Alten Testament?, Zeitschrift für alttestamentliche W issenschaft 77 (1965) 329-332.

51 Cf. Especially. H. Ringgren, Jüdische Apokalyptik. Die Religion in Geschichte und Gegenwart3 vol. I, 464-466.

${ }_{52}$ This period is described in the final part of "The Treatise on the Two Spirits" - 1QS 4, $18-21$

53 On the subject of light-darkness antithesis, the equivalent of the cosmic opposition "body-spirit", compare L.R.Stachowiak, Die Antithese Licht-Finsternis - ein Thema paulinischer Paränese, Tübinger Theologische Quartalschrift 143 (1963) 385-421, and in Polish: Człowiek między świattem a ciemnościq według św. Pawła (Man between light and darkness according to the Saint Paul), Studia Biblijne i Archeologiczne (Poznań 1963) 179- 197.

54 Les antithèses littéraires dans les epitres de Saint Paul, Nouvelle Revue Théologique 70 (1948) 360-387, 


\section{The body-soul antithesis in the Palestinian tradition}

Of course, here the Qumran writings dedicated to the deepest theological reflection and quite diversified anthropology come to the fore. The Qumran Community claimed, as is known, to be the only disponent of an authentic interpretation of the Law, ie practically the entire Old Testament, and to develop it in a teaching office considered as a prophetic in its nature ${ }^{55}$. However, since Qumran represents essentially the Palestinian tradition despite its exclusivism, it is still advisable to consider the orthodox branch of this tradition in rabbinic and late-Jewish writings created in Palestine. Although these statements come mostly from a later period than the Qumran writings, they nevertheless often reflect the very old doctrinal tradition that sometimes goes back to the pre-Christian period. The doctrical infiltration of Greek thought took place here much more slowly and more reluctantly, but its origins were no doubt already present in the Intertestamental period ${ }^{56}$.

The oldest Talmudic tradition to some extent transforms the biblical antithesis of the body-spirit in the sense - also biblical - of the Creator-creation contraposition. "Body and blood" more and more often is considered an exponent of weakness and transience. ${ }^{57}$ At the same time - from the second century before $\mathrm{Chr}^{58}$ - a very significant change takes place in the Orthodox Jewish tradition. In addition to the traditional, comprehensive view of man, taken from the Old Testament, a new one, similar to the Hellenistic contraposition body-soul emerges: according to this view the body is considered as something empty, demanding fulfillment, which by rabbinism is most often described by the term $g \hat{u} f^{59}$, and - in later tradition - an invisible soul, regarded as the organ of personality. The "spirit", on the other hand, begins to lose its dominant position in Judaic anthropology. Since the full development of these speculations falls only to the late age of the second Christian era, they are equally irrelevant to the biblical antithesis as well as to the Qumran antithesis.

What is more interesting, however, is the cosmic-dualistic contraposition of the so-understood "soul" and "body" as two genetically and materially

\footnotetext{
55 This topic is exhaustively discussed by O. Betz, Offenbarung und Schriftforschung in der Qumran-Sekte (Wissenschaftliche Untersuchungen zum Neuen Testament 6), Tübingen 1960.

56 Cf, R. Meyer, Hellenistisches in der rabbinischen Anthropologie, Stuttgart 1937.

57 Such a term is already found in Sir Hebrew 14, 18 (abm wdm) - cf. also Wis 12, 5 and Mt 16, 17 (as an exponent of cognition and natural understanding).

58 Cf. R. Meyer, Art. cit., 115- 116, esp. 116, 9.

59 Ibid.
} 
different spheres. The man represent the synthesis of both of them and chooses between them, thus deciding to lead a life in the spirit of God or a life typical of inferior beings. ${ }^{60}$ This ethical dualistic tone is far from the systematic contrapositions of Greek or Hellenistic-Judaic philosophy ${ }^{61}$; it could not develop properly on the basis of definitely "monistic" Old Testament views. In order to explain the dualistic internal struggles of human beings, another science of a more psychological nature has already been developed in the early rabbinic schools, compatibile with the monolithic anthropological structure in the Old Covenant: the teaching on the two tendencies (jes ârîm) bothering the human heart. ${ }^{62}$ Rabbinism does not associate these two tendencies particularly with the body, but with the organ of a human life of higher order - t.i. with the heart. ${ }^{63}$

\section{The anthropological role of the body-soul antithesis in Qumran}

By approaching a broader discussion of Qumran views on the "body" in contrast to the "spirit", it seems indispensable to define the dependence of terms on literary genres. Naturally, the considerations will concern previously published texts, that is, all of them except for a large part of the documents called as Dead Sea Scrolls from the Qumran cave 4 and 11. Besides, the statements of the utmost importance come from the scrolls from cave I. Interestingly, even among these scrolls, not all texts have the same significance with regard to assessment the problem of "body" or "spirit" and not all of them consider them dualistic. Antithetical connections are confirmed primarily by hymnic excerpts $(1 \mathrm{QH}$ and hymnic ending of $1 \mathrm{QS}$ ); other statements are rather occasional.

The compact lecture of the dualistic theology of the The Qumran Community included in The Treatise on the Two Spirits ${ }^{64}$ does not use the term 1955, 282.

${ }^{61}$ Cf. R. Meyer, Hellenistisches in der rabbinischen Anthropologie, 145- 146; D. Stacey, op. cit., $110 \mathrm{nn}$.

62 Cf. uw. 13.

63 Quite different approach can be found in Qumran theology - cf. R. E. Murphy, Yeser in the Qumran Literature, Biblic 39 (1958) 334-344, especially 335n.

64 Cf. L. Stachowiak, Traktat teologiczno-moralny o dwóch duchach w „Regule Zrzeszenia” $z$ Qumran (Theological-moral treaty on two spirits in the "Rule of the Community" of Qumran), Ateneum Kapłańskie 67(1964) 219-228; idem, Teologiczny temat dwóch duchów w pismach qumranskich (Theological problem of two spirits in the Qumran writings), Zeszyty Naukowe KUL-u 10 (1967) no. 2, 37- 52. 
"body" except for the eschatological perspective mentioned in the final parts of the text (1QS 4, 20-21), which will be discussed below. This state of affairs proves clearly that the "body" did not play - in the dualistic speculations of the Community - the same role as the "spirit", nor was its equivalent antagonist within the internal duality of a man's life or division into two combating camps $^{65}$. The "body", on the other hand, seems to be a very suitable term for expressing the relation of the religious Qumran people towards God; it described his full awareness of his own helplessness and weakness and the necessity of God's intervention. It would certainly be inappropriate to oppose the theoretical considerations presented in Q1 to the religious practice of the Community, visible in Hymns (1QH), nevertheless the "body" seems to be a much more exponent of the spiritual profile of the Community ${ }^{66}$ than of the official theology. At least the hymnic character of $1 \mathrm{QH}$ had to play a certain role, favouring this kind of practical and personal reflection. A dualistic understanding of the situation of a member of the Community with regard to God was based on theological reflection, but at the same time it constantly stimulated and transformed it.

For this reason, some critics prefer to distinguish - based on literary analysis of the writings - between the various developmental stages of the Community: 1QS in its doctrinal part would represent the older, original Qumran tradition, while $1 \mathrm{QH}$ together with the final hymn of $1 \mathrm{QS}$ would be the result of further development of the sect's views, which was possibly subject to Hellenic influences. ${ }^{67}$ In today's state of research on the Qumran writings certain - sometimes far-reaching - changes in the worldview and practices of the Community can not be subject to discussion. The factors influencing these changes remain unclear; one can only presume them. The presence of current Hellenic influences does not seem probable here, considering the completely different concept of the "body" in both cases (see below). It is very likely, however, that the development of dualistic views has been influenced by the progressive radicalization of ethical postulates and separation from the rest of Judaism. Body-spirit antithesis is a typical example of one-sided interpretation of the found Qumran scrolls. Unfortunately, it has had some negative impact on further research. Because the first years of research were marked by the numerous attempts of finding

65 It is about "sons of light" and "sons of darkness".

66 Cf. H. Braun, Römer 7, 7-25 und das Selbstverständnis des Qumran-Frommen, Zeitschrift für Theologie und Kirche 56 (1959) 1- 18.

${ }^{67}$ Cf. for example W. D. Davies, Paul and the Dead Sea Scrolls; Flesh and Spirit. in: The Dead Sea Scrolls and the New Testament (New York 1957) 165. 
Qumran counterparts, which could enable achieving knowledge of the New Testament. Needless to say, in these conditions it was easy to explain many Christian concepts as Qumran terms, but sometimes the meaning appropriate to the New Covenant books was also transferred to the Qumran writings. Among the excellent and substantive explanations of many difficult anthropological issues exaggeration and sensation could not be avoided.

K. G. Kuhn, an eminent and distinguished researcher of the Qumran texts - put forward in 1952 the assertion that, in some of the texts of the Community, bśr means - analogically to the meaning of body in the New Testament - the sphere of sin and the world remaining in contraposition to God. ${ }^{68}$ These views provoked radical opposition from scholars claiming that the concept of "body" in Qumran does not exceed the Old Testament meaning and cannot be attributed an absolute value. ${ }^{69}$ To this day, one can indicate a lot of significant differences of opinions and discrepancies of views about the body-spirit antithesis in the texts from the Dead Sea. R. Meyer, for example ${ }^{70}$ describes the concept of the"body" represented by the scrolls of the cave I in the following way: "It is impossible to prove in any text, even as it is probable, that the body is fighting the spirit ... It is impossible to say that the body belongs to the sphere opposite to God, as well as that the body ${ }^{71}$ can be regarded as a prison for the soul ... Everything supports the fact that the anthropological foundations of the Qumran Commune are still following old ways." ${ }^{\prime 2}$.

In the another eminent work entitled: "Die Religion in Geschichte und Gegenwart" J3 J. Fichtner states as follows: "In the Rule of the Community of people from Qumran, the body designates not only their created nature, but also their politeness ... The body here explicitly enters the realm of perversity". In order to elaborate a clear and objective picture of the Qumran bśr and its possible opposition to the "spirit", an analysis of the most important

68 K. G. Kuhn, peirasmos, hamarta, sarx im Neuen Testament und die damit zusammenhängenden Vorstellungen, Zeitschrift für Theologie und Kirche 49 (1952) 200-222.

69 Cf. W. D. Davies, art. cit., 157- 182 and F. Nötscher, Zur theologischen Terminologie der Qumran-Texte, Bonn 1956, 85-86.

70 In Theologisches Wörterbuch zum Neuen Testament, VII, 113, $11 \mathrm{nn}$.

71 „das Fleisch oder der Körper”.

72 H. Huppenbauer took on an even more extreme position, (Bśr "Fleisch" in den Texten von Qumran, Theologische Zeitschrift 13 (1957) 298-300) maintained in principle in his later monograph entitled: Der Mensch zwischen zwei Welten, Zürich 1959. He seems to deny any significant progress in the development of the meaning of the term "body" in Qumran. His arguments, however, were addressed by professional circles with considerable reserve.

73 III Edition, art. Fleisch und Geist I, 2, Vol. II, 975-976. 
texts should be carried out ${ }^{74}$, excluding, of course, neutral statements or those referring directly to the Old Testament. Such texts include, for example, bgwjt bśrw in the Commentary on the Book of Habakkuk (IQpHab 9, 2): the body has been attributed a purely physical meaning here (see Sir $23,16, \mathrm{Col} 1,22,2,11))^{75}$. Because the Qumran sect grew out of the Old Testament and Judaism, the basic anthropological concepts in Qumran are not different from biblical principles. ${ }^{76}$ Qumran people also share with the Old Testament a positive attitude towards the material world, God's work, thus separating themselves from Greek dualism. Possible negative assessment of the "body" can not be, thus, the result of considering his nature as "material". It is Qumran anthropology to a deeper extent - than it is done in the Old Testament - which emphasizes the distance that separates the Creator from creation, whose natural exponent is the "body". In 1QH 1, 21- 23, he opposes his weakness as being the creatures of God's omnipotence and wisdom with these words: "I am a creature of clay, fashioned with water, foundation of shame, source of impurity, oven of iniquity, building of sin, spirit of mistake, astray, without knowledge and terrified of the judgments of justice, what new can I say?" This is a pessimistic view of a man many critics regard it as a result of depression or obsession of the author on this subject $^{77}$ - continuously repeated in $1 \mathrm{QH}$, relates to the bodily nature of man, although it cannot be considered its result. IQS 11, 21-22 states: "From the dust, after all, I am made and intended for the food of vermin. He is (ie man) a creation - a cluster of clay - and he is supposed to turn to dust" - compare $1 \mathrm{QH}$ 3, 23-23; 12, 25-26; 13, 18.

The technical term for describing human weakness and helplessness of his endeavours is jsr ( $h$ ) $h m r$ or also ( $h)^{\prime}$ fr "or" clay material (gunpowder), according to the Yahwistic description of man's creation in Genesis $2^{78}$. Although the body is nowhere formally defined in this way, nevertheless these words refer

74 The recently published article by J. Pryke, "Spirit" and "Flesh" in the Qumran Documents and some New Testament Texts, Revue de Qumran 5 (1965) 345- 360, does not add any significant new elements to the discussion.

75 An extensive commentary on this text has been published by K. Eiliger Studien zum Habakuk-Kommentar, Tübingen 1953, 202-203.

76 Cf. R. E. Lilly, The Idea of Man in the Qumran Literature, doctoral dissertation, Boston 1962.

77 Cf J. Licht, The Doctrine of the Thanksgiving Scroll, Israel Exploration Journal 6 (1956) $1-13$ (89-101), who does not hesitate (p. 10) to state that it is about an almost pathological abhorrence of human nature, referring to the specific use of the root $n d h$ and $c r w h$ as an expression of sexual disgust when considering human nature contaminated by the impurity of sin.

78 Cf. J. P. Hyall, The View of Man in the Qumran Hodayot, New Testament Studies 2 (1956) $276-284$, especially $278 \mathrm{n}$. 
to it recognized as the most inferior part in a man; Anyway in 1QH 15, 21 both terms: "body" and " a cluster of clay ", are used strictly parallel and have the same meaning: "imperfect, weak man". A sect member can not do anything with his own power, with the power of the "body", if God does not strengthen him (1QH 15, 13-14). This can be expressed negatively by presenting the body as an exponent of a weak human nature deprived of the ennobling gift of the spirit. ${ }^{79}$ Such an assessment of the "body" does not lead to Greek dualism, nor does it make a Qumran bśr a negative feature of the spirit, but highlights the very positive feature of the body: the possibility of sublimation, elevation and even purification what would not be possible in relevant Greek concepts. This is accomplished by the "spirit" understood as a gift: "Through the spirit of the true God's Council, the ways of man and all his inquities will be cleansed so that he may see the light of life. And through the spirit of the holy Assembly he will be cleansed in his truth from all his sins. The remission of his sin will be made by the spirit of righteousness and humility, and by surrendering (his soul? $-n f^{\prime} w^{\prime}$ ) to all the commandments of God, he will cleanse his body so that he may be sprinkled with water of purification..." (1QS 3, 6-8) ${ }^{80}$.

This takes place in a certain - imperfect way- in temporal life, yet thoroughly in the eschatological period (1QS 4, 20-21). In this way once again the fundamentally positive attitude of Qumran theology to the material side of man has been confirmed.

According to the Community's often expressed conviction, the present came under the rule of Beliali ${ }^{81}$ and with it the man was subject to the sphere of his influence. It should be expected that the most vulnerable ground for this kind of influence will be the most inferior and at the same time the weakest part of the human being, and thus the body. The analysis of the texts will show in what sense the body reacts to contacts with the world of iniquity and whether the fight will ensue on this occasion.

The general conviction present in the Old Testament about the common sinfulness of the human race is connected with the body in $1 \mathrm{QH} 4,29-30$ : "What is the body in comparison with this (namely, the works of God's power and omnipotence described above)? And what is the creation of clay to do such wonderful miracles? Although he is immersed in sins from the time he was

79 D. Flusser, The Dead Sea Scrolls and Pre-Pauline Christianity, 255, prefers to speak here of "the lack of a gift of grace".

80 This function of spirit is discussed in more detail in: Coppens, Le don de l'esprit d'après les textes de Qumrân et le quatrième Evangile. in: Evangile de Jean, (Bruges 1958), 209-223.

81 Cf. technical expression bmmslt blj'l: 1QS 1, 18.23; 2, 19 and 1QM 14, 9. 
in the womb of his mother, and until his old age he will remain subject to sinful perversity. "There is no direct connection between the body and sin - Hebrew whwh refers not to the bśr, but to man; - the subject of sinfulness, however, is not generally the "son of Adam", but man as a "creature made of clay", regarded as a "body". Apparently, both of these concepts remind the Qumran poet of sin and guilt, yet not considered as present, but as a chronic tendency to perversity. The position even more opposed to God refers to the physical nature of man in CD 1, 2 and 1QM (Rule of War) 4, 3. In the first text, "those who despise God", so they are most likely Israelites who act against the principles of the Community, are considered to be the equivalent of the "body". Though the Old Testament context of the statement (see Jeremiah 25:31, Oz 4:1) is universalistic, E. Cothenet ${ }^{82}$ is right when he writes: "Despite the universalism of the formula, the author's attention is focused on the Israeli perspective." The second text deals with the eschatological opponents of the sect and is taken from the inscription on the banner of a military unit of a hundred soldiers: "From God comes a hand that fights against a perverse body"83. The last statement is all the more important because it compares the "body" with the exponent of perversity in Qumran (' $w / h$ ); moreover, the similar meaning is expressed in 1QS, 11, 9 and 1QS 12, 12, which states that body is "fulfilled with guilt". Some commentators suspect that the text was later supplemented by the copyist in IQM $12,12^{84}$, nevertheless, such an interpretation formulated in the heart of the sect would confirm the recognition of the body as susceptible to sin and guilt. The "body of wickedness" does not naturally have the technical meaning of the "sphere", as it is in the New Testament, because it defines a certain category of people. The choice of the term bśr for this purpose, as well as the hidden opposition between people outside the Community, that is "body" and people living within the Community according to the principle of "spirit", are highly significant. This will be confirmed by the analysis of several statements of the final part of 1QS. The extension of meaning of term "body council" (swd bśr) in 1QS 11, 6-7 does not completely coincide with the extension of meaning of term "sons of darkness" leading life outside the Community. The equivalents of this concept are "people" or "sons of Adam", so the hypothesis of collective meaning seems to be the most justified in this point. ${ }^{85}$

82 Les Textes de Qumran II, Paris 1963, 149.

83 As for the commentary on the text, see J. Carmignac, La Règle de la Guerre, Paris 1958, 64.

84 Cf. J. Carmignac, op. cit., 182, however more accurate view is held by J. van der Pioeg, Le rouleau de la Guerre, Leiden 1959, 148.

85 Cf. W. Tyloch, Rękopisy z Qumran nad Morzem Martwym (Qumran Dead Sea Scrolls), Warszawa 1963, 115 uw. 10. 
Nevertheless, it is not neutral, as R. Meyer supposes, citing as a parallel lQ S b 3,28 and 1Q 34 fr $3 \mathrm{I}, 3^{86}$.

We should pay attention not only to the equivalents, but also to the opposites. In this context, the author of the final psalm admits the enormity of Wisdom, which was attributed to him. This gift is inaccessible to the "counsel of the body" and is only granted by God as "His eternal property" $(11,7)$ as participation in the fate of the saints ( $g w r l a d w s j m$ ) with the "sons of heaven" $(11,8)$. There is, therefore, a contrast between the "human congregation" whose exponent is "the body" and the angels that are characterized by holiness. The adjective "saint" appears again, besides the already mentioned gwrl qdwsjm, in the term "foundation of the holy building" (wswd mbnjt qwdś in 11, 8) and "holy house of Israel" which is synonymous with "eternal plant" (1QS 8, 5; compare 11, 8) ${ }^{87}$. The author of the hymn essentially belongs to the "fate of God" (1QS 1, 10, 2, 2, IQM 17, 7) or "the fate of the saints" (see: 1QH 11, 11; 1Q 36 I, 3). Only his actual sins confirm that he did not completely free himself - leading earthly life - from the reach of the forces of darkness ${ }^{88}$ : "But I belong to the impious mankind and to the congregatio of a perverse body." What this perversity consists of is described by the next words, listing three classic categories of $\sin \left(' w w n, p s\right.$ ' and $\left.h t^{\prime} h\right)$, although here too it is difficult to attribute to the "body" the technical meaning of the subject of iniquity in the anthropological sense. Some suggestions in this direction are implied by the words 1QS 11, 12: "If I fall through the sin of the body (my exculpation will be done according to the righteousness of God)". Whether the "sin of the body" means a certain special category of crime or, more generally, the sinful nature of human existence ${ }^{89}$, in any case it opposes God's justice, i.e. can be recognized as belonging to a more general God vs man contraposition considered in the anthropological perspective.

G. Baumbaeh ${ }^{90}$ explains the significance of this text in the following way: "The limitation of man as creation and his susceptibility to sin have been highlighted particularly clearly in the final psalm of the Rule of the Community."

86 art. cit., $110,15-24$.

87 This issue is discussed in more detail in F. Nötscher, Heiligkeit in den Qumranschriften, Revue de Qumran 2 (1960) 161- 181 and R. E. Murphy, BŚR in the Qumran Literature and SARKS in the Epistle to the Romans. in: Sacra Pagina (Paris 1959), 60-76, especially 65-67.

88 Cf. remark 53.

89 Cf. R. Meyer, art. cit., 112, 31.

90 Der Dualismus in der Sektenrolle im Vergleich mit dem Dualismus in den spätjüdischen Apokalypsen und dem Johannes-Evangelium, doctoral dissertation, Berlin 1956 (published as: Qumran und das Johannes - Evangelium, Berlin 1959, 29). 
As mentioned above, the body, in spite of its weakness and susceptibility to sin, can be purified by the gift of the spirit. It would be left to explain whether and what is the role of the "spirit of perversity" with regard to the aspirations of the body and whether the process of the actual and eschatological purification of the body is the result of a fight between the body and the spirit by analogy to the contraposition of the two spirits ? ${ }^{91}$

This part of the discussion again refers us to the most systematic lecture of Qumran theology and anthropology, namely to The Treatise on the Two Spirits in 1QS 3, 13-4, 26. Its last part $(4,15-26)$ contains a recapitulation of the dualistic description of man's life in an eschatological perspective. As a result of the victory of the truth $(4,19)$ and the destruction of iniquities $(4,18-19,23)$ there will be the purification of some of the leftovers of perversity ('wlh $)^{92}$ : "Then God will purify all the deeds of man in His own truth and make a choice for Himself among the sons of men, removing all the spirit of unrighteousness from within his body and cleanses him with the holy spirit from all shameful deeds." The text belongs to the most difficult ones in the "Rule of the Community". Apart from the expression mbnj' jś (probably to be read: mbnh ' $j$ 's - compare $1 \mathrm{QH} 13,15)$, which seems less important in these considerations, the meaning of the fundamental expression $m t k m w$ bśr is unclear. Y. Yadin ${ }^{93}$ comments on the term $m k m w$ and P. Guillbert ${ }^{94}$ is following him on the basis of an analogy with Arabic as for the meaning of "the inward part of flesh", which seems to be quite likely. Nevertheless, the interpretation of this text as an extended suffix, combined with the word twk (inward), which is already suggested by the first translator of the 1QS W. H. Brownlee ${ }^{95}$, is widespread. Yet another explanation was presented on the basis of the parallel text 1Q 36, 14, 2 by J.T. Milik ${ }^{96}$, who adopted the meaning "dirt, contamination" in relation to the body, based on the Syrian word ketam (= soiled, contaminated).

Whatever the meaning of the individual terms is, the body here is the subject of contamination and remains in communication with the perpetrator of this activity - t.i. the "spirit of iniquity" ( $r w h$ ' $w l h)$. However, the opposition

91 L. Stachowiak, Temat dwóch duchów..., 48-52.

92 Literary analysis of this fragment can be found in J. Licht, An Analysis of the Treatise on the Two Spirits in DSD, Scripta Hierosolymitana 4 (1958) 88-100.

93 A Note on DSD IV, 20, Journal of Biblical Literature 74 (1955) 41-43.

$94 \quad$ Les Textes de Qumran, Paris 1961, vol. I, 37.

95 The Dead Sea Manual of Discipline, Bulletin of the American Schools of Oriental Research, Supplementary Studies 10-12 (New Heaven 1951) 17.

96 Qumran Cave I, Oxford 1955, 141-142. 
is not directly between the body and the spirit of holiness, but rather between the two spirits. Similarly, it should be emphasized that the spirit of sanctification by purifying the body, destroys the spirit of iniquity and not the body itself. It follows unambiguously that the association of the spirit of iniquity and the body as an exponent of weakness and even human sin is a fait accompli in Qumran mentality, although they are not two equal or specific forces: while the "spirit of iniquity" is active, fights, the body plays a passive, subjective role.

Two parallel texts of the Hymns cast a further light on the relationship of the spirit to the body: 1QH 13,13-14 and 17,25. They use the very characteristic term $r w h$ bśr ("bodily spirit"!), along with the less paradoxical jsr bśr $r^{97}$ ("the tendency of the body", possibly "a bodily creation "- 1QS 10, 23). Essentially, "spirit" and "body" are two elements of a very different organic entirety of man. $1 \mathrm{QH}$ opposes them as a state of weakness and sinfulness in a man (bśr) and the aspect of God, opening the way to his justice $(r w h)^{98}$. The spirit understood in this way is not a gift, but a natural endowment of the human being, which he received, just like the body, from God"99. In a man who lives in the temporal world subordinated to the reign of Belial, this spirit is more susceptible to the action of the spirit or spirits of iniquity, is religiously and ethically weak, it is a "bodily spirit". In 1Qh 17, 25 the psalmist begs for God's help against such $r w h w t$, inclining him towards evil. The text is, however, damaged in this place; however, the mention of the rejection of "what God hates" $(17,24)$ makes such an interpretation of the nature of these spirits certain.

A member of the Community left to himself is powerless in this struggle, because his "bodily spirit" easily opens the way for the deceptive actions of the forces of perversity. On the ethical level, one could speak of "bad inclination" or "bodily inclination" (see the above-quoted jsr bśr expression). The second statement refers to the understanding of God's plans; "Bodily spirit" makes it impossible to practice it in everyday practice or significantly reduces it $(1 \mathrm{QH}$ $13,13-15)$. It is, however, characteristic, that in addition to the normal description of the human bodily being: "born of a woman ... a building made of dust crushed with water ... whose essence is guilt and sin (?)", also here this kind of spirit is connected with the rule of a perverse "spirit". Despite the not very clear contours of the body as the sphere of the "spirit of perversity", it is an

element facilitating access of such a spirit. In other words, the human spirit

97 Cf. remark 13.

98 Cf. also R.E. Murphy, BŚR in the Qumran Literature..., 62.

99 Cf. F. Nötscher, Geist und Geister in den Texten von Qumran. in: Mélanges bibliques... A. Robert (Paris 1957) 305-315. 
seems to be a neutral factor in the struggle between the spirit of truth and the spirit of iniquity. Only a closer definition of the bśr of body, attributes it a special susceptibility to bad influences.

\section{Conclusion: the body-soul antithesis' role in anthropology}

Summing up this analysis of the most important anthropological moments of the Qumran concept of "body", it should be stated that the development of the concept in relation to the Old Testament is beyond discussion. This notion is developed not only in the direction initiated by Apocalyptic, but it presents in an extremely radical way the ancient statements of the Old Testament. The "body" in Qumran is not only regarded as an exponent of weakness, but also as a factor facilitating the access of sin. Nevertheless, the body is not a sphere of sin, nor is it irrevocably tainted with sin. It is certainly impossible to point out any influence of the dualistic Hellenistic anthropology on the Qumran Commune of the Dead Sea.

Furthermore, one cannot find anywhere in Qumran antropology, the struggle between body and spirit in a strict sense. Qumran anthropology presents the opposition between two spirits, which, until the time of final purification, remain in a constant struggle; the body is entangled in this struggle, but not as a partner, but the subject of human weakness, open to successful attacks of the spirit of perversity. If the "body" sometimes represents temporality influenced by Belial in Qumran, then it is not "spirit", but God himself with the Prince of Ligh, that is a part of this opposition. It is therefore only about the new - the more dualistic - formulation of the old Old Testament opposition. Admittedly the new opposition of great importance to anthropology is the absence or presence of the spirit of truth, the gift of God. This spirit makes man who is "bodily", vulnerable to the weakness of the body, become "spiritual", prone to God's influence. Finally, it must be emphasized that as part of the eschatological renewal, the body will not be destroyed, the "spirit" will not be freed from it, as Hellenism would hold it, but the spirit of truth will cleanse the body of the remnants of iniquity that clung to it during the battle of the two spirits.

However, this will not be the result of the struggle of the spirit with the body, but the decisive intervention of God. It is difficult to talk about "dualism" or "dualistic" statements in the proper sense of the word, both in the Old Testament and in the literature related to it. The theological reflection of the Old Covenant persistently fought against all tendencies to consider evil or sin as an element independent of or existing beside God. Anyway, the description 
of the God-Creator and the idea of God's free choice of Israel is tantamount to overcoming duality in the broadest sense of this word ${ }^{100}$. Interestingly, the Qumran Commune, whose dualistic tendencies are all too obvious, is holding the same view. It does not hesitate to recognize the evil spirit or our evil propensities as a creation of God, making him the Creator of both the spirit of truth and iniquity. It seems that theology of Israel - especially after the period of slavery - has retained only a general anti-dualistic tendency, yet without rejecting side, original or foreign antithetic elements in liturgical formulas, moral instructions, etc. It is also possible that even the sacerdotal tradition did not remain free from such influences, as E. Stauffer rightly supposes ${ }^{101}$. In any case, this dualistic penetration has left very slight traces in the anthropological terminology of the Old Testament.

Among the later books, one can observe the deepening of the dualistic thought only in Hebrew and Greek Book of Sirach, accompanied with some psychological aspect. As a result of further observation of the developmental line of the anthropological tradition, it can be assumed that the proper transition from the non-dualistic forms of the Old Testament described above to the well- known anthropological dualism has taken place in the intertestamental literature. From contingent statements about opposing concepts, technical formulas of a clearly dualistic character are now being created; from transitory juxtapositions, two kinds of schemes, as those of two spirits, "two tendencies", etc. emerge. The manifestations of dualistic thought are most prominent and visible in the Testaments of the Twelfth Patriarchs, a repeatedly edited and interpolated writing, but in the original undoubtedly of Judaic origin; to a lesser extent it is present in the Book of Enoch and the Book of Jubilees, books of immensely complicated literary tradition.

The simplest, but by no means the only solution to the problem would be looking for the causal relationships between this tradition and the Qumran context. This would be tantamount to the conclusion, that it was Qumran, where the entire development of the dualistic anthropological reflection was concentrated; however, it does not fully correspond to either the literary or theological data of the analysis carried out here. Even in this case, the issue of the reasons for such intensive development of dualistic forms would remain open. It would not be explained ultimately by the specifically exclusive and even dualistic understanding of its own situation by the sect itself. Only in a sense it was the result 
of the internal and external conditions of the Community, and to a much greater extent, it was the consequence of the "theoretical" anthropological dualism. As for other ancillary influences, it should be noted that the late Jewish Apocalyptic along with the eschatological expectations has undoubtedly led to the radicalization of theological views and ethical postulates; it is represented by the science of "two eons", which Judaism could easily project into the anthropological plane. Moreover, the role of "knowledge" and "wisdom" in the anthropological Qumran texts gives the impression of certain influences on the part of pregnosis or gnosis. However, because the documentation of Gnostic systems dates back to the second century and at most the first century before Christ, only gnostic influence of the last two Christian centuries could be considered as relevant ${ }^{102}$.

Analogously to the later systems, it can be concluded that "gnosis" favored the formation of anthropological antitheses, the latter cannot however be explained only by means of a general reference to gnosis. ${ }^{103}$ The Iranian influence was already discussed in more detail above. The intertestamental dualistic anthropology is mostly based on biblical elements, although some schemes have developed not without contribution of foreign influences, which, however, were not direct but mediated by the unorthodox Judaism or syncretic forms. As a result of those tendencies a dualistic atmosphere was created in communities particularly susceptible to their influence, intensified by internal-Judaic radicalism and Apocalyptic. This atmosphere influenced to some extent all the communities, which demonstrated intense theological reflection, using also common formulations, devoid of individual theological features; the latter were given to them by particular communities, depending on the specific ideological assumptions they adopted.

In Palestine, the propagator of these tendencies - and one of the most active ones - was undoubtedly the Qumran Community. However, it must not be forgotten that it was neither the only nor perhaps the most outstanding. Until now, the accidental discoveries and careful work of critics have confirmed that Qumran can be regarded as a community that has found many answers to its questions in a dualistic context. For scientific investigation it is important that it spoke its original language, highlighting in its entirety the issue of the old and the Intertestamental anthropological dualism.

102 Bo Reicke, Traces of Gnosticism in the Dead Sea Scrolls, New Testament Studies 1 (1954) 134-140; R. P. Casey, Gnosis, Gnosticism and the New Testament. in: Festschrift Dodd (Cambridge 1956) $52-80$ and articles in above cited remark 1 from the collection Le origini dello gnosticismo - The Origins of Gnosticism, Leiden 1967.

103 Cf. U. Bianchi, Le dualisme en histoire de religions, Revue do l'Histoire des Religions 159 (1961) 7. 